\title{
IgG4-Related Disease as Mimicker of Malignancy
}

\author{
WanLi Zhou ${ }^{1}$ (1) - Timothy Murray ${ }^{2} \cdot$ Liliana Cartagena $^{3} \cdot$ Howard Lim $^{4} \cdot$ David F. Schaeffer $^{5} \cdot$ Graham W. Slack $^{5}$. \\ Brian F. Skinnider ${ }^{5} \cdot$ Eric Lam ${ }^{6} \cdot$ Robert Irvine $^{7}$. Stephen Chung $^{8} \cdot$ Andre Mattman $^{5} \cdot$ Silvia D. Chang ${ }^{2}$. \\ Mollie N. Carruthers ${ }^{3} \cdot$ Luke Y. C. Chen ${ }^{9}$
}

Accepted: 11 May 2021 / Published online: 27 May 2021

(C) The Author(s) 2021

\begin{abstract}
Background IgG4-related disease (IgG4-RD) is an immune-mediated disease that may present as a tumefactive lesion in nearly any organ. These mass lesions often resemble malignancy both clinically and radiologically, and some patients undergo surgical resection which could possibly be avoided with early recognition of IgG4-RD. We performed a retrospective single-center study examining how many patients with IgG4-RD were initially believed to have malignancy, with particular attention to those who underwent potentially avoidable surgical procedures.

Methods Sixty-three patients with biopsy confirmed IgG4-related disease were included. Clinical, laboratory, radiological, and histological data were collected and analyzed.

Results Over $60 \%$ of patients (38/63) were initially thought to have a malignancy when they initially presented with symptomatic IgG4-RD. The most common types of malignancy suspected were lymphoma (18/38) and pancreatic cancer (11/38). Of the 38 patients with suspected malignancy, 14 underwent an invasive intervention either to alleviate the severity of their symptoms or as treatment for their presumed malignancy. These included Whipple resection/attempted Whipple (3), nephrectomy (3), bile duct resection and reconstruction (1), removal of other abdominal/retroperitoneal masses (3), and stenting of obstructed organs (4). Conclusion IgG4-RD should be on the differential diagnosis of patients with mass lesions, in particular those with pancreatic masses and obstructive jaundice, extensive lymphadenopathy, or retroperitoneal masses. Oncologists and other physicians involved in cancer care should be aware of the various manifestations and diagnostic approach to IgG4-RD in order to provide accurate diagnosis and minimize unnecessary invasive procedures. While some procedures in this study, such as stenting of obstructed organs, were required regardless of diagnosis, others could have potentially been avoided or attenuated with early recognition of IgG4-RD. Patients with mass lesions suspicious for IgG4-RD should have serum protein electrophoresis, IgG subclass measurement, and, where possible, tissue biopsy before undergoing major surgical resection. Consultation with a physician experienced in IgG4-RD is recommended.
\end{abstract}

Keywords IgG4-related disease - Tumefactive $\cdot$ Autoimmune pancreatitis · Surgical resection $\cdot$ Invasive intervention Malignancy mimicker

This article is part of the Topical Collection on Medicine

Luke Y. C. Chen

lchen2@bccancer.bc.ca

1 Department of Medicine, University of British Columbia, Vancouver, British Columbia, Canada

2 Department of Radiology, University of British Columbia, Vancouver, British Columbia, Canada

3 Division of Rheumatology, University of British Columbia, Vancouver, British Columbia, Canada

4 Division of Medical Oncology, BC Cancer Agency, University of British Columbia, Vancouver, British Columbia, Canada
5 Department of Pathology and Laboratory Medicine, University of British Columbia, Vancouver, British Columbia, Canada

6 Division of Gastroenterology, University of British Columbia, Vancouver, British Columbia, Canada

7 Division of Otolaryngology, University of British Columbia, Vancouver, British Columbia, Canada

8 Department of Surgery, University of British Columbia, Vancouver, British Columbia, Canada

9 Division of Hematology, University of British Columbia, 2775 Laurel St, 10th Floor, Vancouver, BC V5Z 1M9, Canada 


\section{Introduction}

IgG4-related disease is an immune-mediated disease characterized by tumefactive lesions, typically in glandular tissue [1]. The disease can affect nearly any organ except synovial tissue, with a median age of diagnosis of 60-70 in most large studies and a 2:1 male:female ratio [2]. The standard treatment of IgG4-RD is corticosteroids and/or rituximab, and a good response within 2-4 weeks is characteristic of the disease [1, 2].

With the exception of classic autoimmune pancreatitis [3], traditionally all presentations of IgG4-RD require histologic confirmation of diagnosis. Tissue diagnosis is crucial to distinguish the disease from potential mimickers such as multicentric Castleman disease, and to exclude malignant neoplasms $[4,5]$. The International Consensus Criteria for diagnosis of IgG4-related includes [2]:

i) A dense polyclonal lymphoplasmacytic infiltrate enriched with IgG4-positive plasma cells

ii) Storiform fibrosis, and

iii) Obliterative phlebitis

The number of IgG4 positive plasma cells per high powered field varies according to the tissue, from $>10 /$ high power field (hpf) in meninges to $>100 / \mathrm{hpf}$ in skin; but in all sites, the $\mathrm{IgG} 4 / \mathrm{IgG}$ ratio is typically $>40 \%$.

Recently, the American College of Rheumatology/ European League Against Rheumatism published a new set of classification criteria for the diagnosis of IgG4-related disease [6]. These new criteria are based on a set of clinical, serological, radiological, and pathological characteristics. Each item in the clinical, serological, radiological, and pathological categories is scored based on the strength of their association with IgG4-RD. The ACR/EULAR group used a diagnosis threshold of 20 points or above, using these criteria, with a specificity of $97.8 \%$ and a sensitivity of $82 \%$. One of the benefits of this new classification criteria is that patients may be diagnosed with IgG4-RD without the need for a biopsy - which, up until recently, has been the gold standard of diagnosing the disease [6].

Since the discovery of IgG4-RD in the early 2000 s, its differentiation from malignant causes of tumefactive lesions has been a difficult problem for clinicians and radiologists. There are numerous case reports of IgG4-RD presenting as mass lesions and being mistaken for malignancy in organs such as pancreas, lung, mediastinum, and gallbladder [7-9]. The discovery of IgG4-related pancreatitis was driven largely by the fact that many patients were undergoing potentially unnecessary Whipple's resections only to find that they had autoimmune pancreatitis, which is treatable with medical therapy, rather than pancreatic cancer [5]. When Japanese investigators looked for biomarkers to distinguish autoimmune pancreatitis from pancreatic cancer, they discovered that patients with autoimmune pancreatitis had a polyclonal hypergammaglobulinemia with betagamma bridging which was in fact elevated serum IgG4 [5]. Subsequently, IgG4-plasma cell enriched infiltrates were discovered in numerous organs, and the term "IgG4-related disease" was coined [4]. Conversely, elevated serum IgG4 and IgG4-positive plasma cells can also be a reactive finding in other conditions [10], and some patients initially thought to have IgG4-RD may in fact have clonal neoplasms such as lymphoma and chronic myelomonocytic leukemia [11-13].

Malignancy may also occur contemporaneously with IgG4-RD [14]. Lymphoma is one of the common cancer occurrence reported in literature in IgG4-RD patients, however, the physiological mechanisms are not well understood [13]. Most of these reports come from East Asian countries and consist of extranodal marginal zone lymphoma of mucosaassociated lymphoid tissue and non-Hodgkin lymphoma [15]. There have also been case reports of pancreatic cancer in IgG4-RD patients [16]. In addition, there was one case report of simultaneous occurrence of IgG4-related tubulointerstitial nephritis and colon adenocarcinoma with hepatic metastasis [17]. These case reports highlights that although IgG4-RD and malignancies may be mimickers of each other, the two are not mutually exclusive, and it may be prudent to screen for co-existing malignancy in the right circumstances.

We therefore reviewed our experience with $\mathrm{IgG} 4-\mathrm{RD}$ at a single institution with a focus on ruling malignancy in or out. We wish to highlight the features of IgG4-RD pertinent to clinical oncologists in order that patients with IgG4-RD may avoid unnecessary surgical resections and biopsies.

\section{Materials and Methods}

Institutional review board approval was obtained through the Vancouver Coastal Health Research Institute clinical research ethics board (H17-02765). All methods were carried out in accordance with relevant guidelines and regulations. Informed consent for participation and publication was obtained from all subjects, or if subjects are under 18, from a parent and/or legal guardian.

We performed a single-center retrospective chart review of 63 patients with biopsy-confirmed IgG4-related disease at Vancouver General Hospital in Vancouver, British Columbia, from 2015 to 2019. All patients underwent pathology review by an expert pathologist (DFS, GWS, BFS) according to the Consensus Statement on the pathology of IgG4$\mathrm{RD}$ [2] after referral to our center. Serum IgG4 was measured by immunonephelometry, with pre-emptive precautions 
against hook effect error, prior to October 2016, and by liquid chromatography tandem mass spectrometry thereafter [18].

Demographic information from all patients, including their age at presentation, age at diagnosis, gender, ethnicity, and any history of malignancies was extracted into a deidentified database. Disease characterizing information, including site of organ involvement, initial IgG4 (or first available IgG4 level), CRP, CBC, and tumor marker were recorded, if available. We examined whether patients were suspected of having a malignancy, all surgical intervention and procedures undertaken, and complications related to these procedures.

Some patients received prior workup with their family physicians, and/or surgical oncologists if they if they presented prior to 2015. In these cases, the laboratory investigations (i.e., serum $\operatorname{IgG} 4, \operatorname{IgG}$ ) were done after referral and may not reflect their initial serum IgG4 on presentation of their disease.

\section{Results}

Sixty-three patients with IgG4-related disease were included in this study. Patient demographics, year of correct diagnosis, and organ site involvement of IgG4-RD are summarized in Table 1 . The earliest diagnosed case in our center dates back to 2012 with 3 cases. The cases remained low until 2015, averaging 2-4 cases per year. The diagnosis rate went up significantly starting in 2016 to 2019 . The most common sites of IgG4-RD involvement included the salivary glands $(n=35 /$ $63)$, pancreas $(n=17 / 63)$, and lymph nodes $(18 / 63)$. We also report rarer sites such as coronary artery, pericardium, and hard palate.

Table 2 summarizes the most common malignancy to mimic IgG4-RD in our patients, and the types of invasive interventions patients with an original diagnosis of malignancy underwent. Lymphoma and pancreatic cancer comprised of 29 out of 38 cases. The other malignancy mimics included cholangiocarcinoma, gastric cancer, cecal cancer, renal cancer, mesothelioma, and prostate cancer. The most common invasive interventions included Whipple procedure (3/14), nephrectomy (3/14), and IR stent insertion (4/14). Other invasive interventions include laparoscopic mass resection, hemicolectomy, and extensive biliary reconstruction.

Table 3 summarizes the various organ site involvement of IgG4-RD, and the types of malignancy they mimicked in our cohort of patients. Some sites, such as lymph node involvement, can be mimickers of various types of malignancies, including lymphoma, pancreatic/GI cancer, cholangiocarcinoma, renal cell carcinoma, and prostate cancer. Salivary gland involvement also mimics a variety of malignancies, including lymphoma, pancreatic, colorectal, and gastric cancer. Specific organ sites, such as lung, have a limited number of malignant
Table 1 Patient demographics

\begin{tabular}{|c|c|}
\hline \multicolumn{2}{|l|}{ Gender } \\
\hline $\mathrm{M}$ & 40 \\
\hline $\mathrm{F}$ & 23 \\
\hline Mean age (years) & 64.9 \\
\hline Median age (years) & 67 \\
\hline \multicolumn{2}{|l|}{ Ethnicity } \\
\hline Asian & 38 \\
\hline White & 15 \\
\hline South Asian & 7 \\
\hline Hispanic & 2 \\
\hline Arab & 1 \\
\hline African American & 0 \\
\hline \multicolumn{2}{|l|}{ Year of diagnosis } \\
\hline 2012 & 3 \\
\hline 2013 & 4 \\
\hline 2014 & 4 \\
\hline 2015 & 2 \\
\hline 2016 & 17 \\
\hline 2017 & 16 \\
\hline 2018 & 12 \\
\hline 2019 & 5 \\
\hline \multicolumn{2}{|l|}{ Organ involvement } \\
\hline Salivary gland & 35 \\
\hline Lymph node & 18 \\
\hline Pancreas & 17 \\
\hline Lacrimal gland & 16 \\
\hline Kidney & 9 \\
\hline Lung & 6 \\
\hline Biliary & 4 \\
\hline Liver & 4 \\
\hline Retroperitoneum & 4 \\
\hline Sinus & 3 \\
\hline Aorta & 2 \\
\hline Adrenal gland & 1 \\
\hline Cecum & 1 \\
\hline Coronary artery & 1 \\
\hline Splenic vein & 1 \\
\hline Pericardium & 1 \\
\hline Peri-urethra & 1 \\
\hline Prostate gland & 1 \\
\hline Hard Palate & 1 \\
\hline
\end{tabular}

mimickers, limited to only mesothelioma in our study population.

Table 4 contains synopses of each case where the patient underwent an invasive procedure intended as treatment for their presumed malignancy. Common symptoms included pain, painless jaundice, obstructive symptoms, constitutional symptoms, which are often considered severe and warranted urgent treatment. All 14 patients had radiographic findings 
Table 2 Malignancy procedures mimickers and invasive

$\begin{array}{lr}\text { Presumed malignancy }(n=38) & 18 \\ \text { Lymphoma } & 11 \\ \text { Pancreatic cancer } & 2 \\ \text { Cholangiocarcinoma } & 1 \\ \text { Gastric } & 1 \\ \text { Cecum } & 1 \\ \text { Renal } & 1 \\ \text { Sarcoid } & 1 \\ \text { Mesothelioma } & 1 \\ \text { Prostate } & \\ \text { Invasive intervention }(n=14) & 4 \\ \text { IR stent insertion } & 3 \\ \text { Whipple procedure } & 3 \\ \text { Nephrectomy } & 2 \\ \text { Laparotomy mass resection } & 1 \\ \text { Hemicolectomy } & 1 \\ \text { Biliary reconstruction } & \end{array}$

highly suspicious for malignancy such as discrete masses in the affected organs. In some cases, the mass was exerting downstream effects such as intestinal/biliary obstruction, IVC compression. A great number of cases that resulted in invasive intervention were done prior to $2015(n=6 / 14)$. Another 7 cases were done between 2016 and 2018. Only one case of surgical resection as a result of malignancy mimicker was done in 2019. Interestingly, one patient (row 14) had an elevated CA $19-9$ marker of $>800 \mathrm{u} / \mathrm{mL}$.

Figures 1, 2, and 3 illustrate radiographical findings of three patients with urogenital/gastrointestinal involvement of their IgG4-RD. They highlight the resemblance between the tumefactive lesions in IgG4-RD and malignant masses.

The patient illustrated in Fig. 1 presented with acute urinary retention and jaundice, and MRI results showed heterogeneity of prostate gland, irregular enhancement, and multiple peripheral wedge shaped non-enhancing regions.

The patient illustrated in Fig. 2 was found on CT to have a well demarcated splenic mass. He also had a borderline elevated serum IgG4 level on presentation. A core biopsy of the perirenal mass revealed increased expression of IgG4 positive plasma cells on immunohistochemistry.

Figure 3 represents a patient who presented with lymphadenopathy and urinary symptoms. MRI of the pelvis revealed periurethral mass displacing the vagina posteriorly. She had an initial IgG4 of $5.42 \mathrm{~g} / \mathrm{L}$ (normal $<1.35 \mathrm{~g} / \mathrm{L}$ ). The excisional biopsy of her cervical lymph node revealed reactive follicular hyperplasia, and it was eventual biopsy of the periurethral mass that showed "fibromuscular stroma infiltrated by chronic inflammatory cells, increased IgG4 positive plasma cells.”

\section{Discussion}

One of the most common manifestations of IgG4-related disease is the development of a mass, or tumefactive lesion, which can involve virtually any organ in the body. Both the Consensus Statement on the pathology of IgG4-RD [2] and the recent 2019 EULAR/ACR criteria [6] are designed to help exclude mimickers of IgG4-RD such as cancer, vasculitis, and rare conditions such as multicentric Castleman disease. The importance of timely diagnosis of IgG4-RD has been amply

Table 3 IgG4-RD organ site involvement and corresponding malignancy mimickers

\begin{tabular}{|c|c|c|c|c|c|c|c|c|}
\hline \multirow[b]{2}{*}{$\begin{array}{l}\text { IgG4-RD Organ } \\
\text { site }\end{array}$} & \multicolumn{8}{|c|}{ Malignancy mimicker } \\
\hline & Lymphoma & $\begin{array}{l}\text { Pancreatic } \\
\text { Cancer }\end{array}$ & $\begin{array}{l}\text { Colorectal } \\
\text { cancer }\end{array}$ & Cholangiocarcinoma & $\begin{array}{l}\text { Gastric } \\
\text { cancer }\end{array}$ & $\begin{array}{l}\text { Renal cell } \\
\text { carcinoma }\end{array}$ & $\begin{array}{l}\text { Prostate } \\
\text { cancer }\end{array}$ & Mesothelioma \\
\hline Salivary gland & $\sqrt{\square}$ & $\sqrt{\square}$ & $\sqrt{\square}$ & $\sqrt{\square}$ & $\sqrt{ } \square$ & & & \\
\hline Lymph node(s) & $\sqrt{\square}$ & $\checkmark \square$ & $\sqrt{\square}$ & $\sqrt{\square}$ & $\sqrt{ } \square$ & $\sqrt{\square}$ & $\checkmark \square$ & \\
\hline Pancreas & $\sqrt{\square}$ & $\checkmark \square$ & & $\sqrt{\square}$ & $\sqrt{ } \square$ & & & \\
\hline Lacrimal gland & $\sqrt{\square}$ & $\checkmark \square$ & & & & & & \\
\hline Kidney & $\sqrt{ } \square$ & & & & & $\sqrt{ } \square$ & & \\
\hline Lung & & & & & & & & $\sqrt{ } \square$ \\
\hline Biliary tract & $\sqrt{\square}$ & & & $\sqrt{\square}$ & & & & \\
\hline Sinus & $\sqrt{ } \square$ & $\checkmark \square$ & & & & & & \\
\hline \multicolumn{9}{|l|}{ Aorta } \\
\hline Prostate & & & & & & & $\sqrt{ } \square$ & \\
\hline \multicolumn{9}{|l|}{ Coronary artery } \\
\hline Cecum & $\sqrt{\square}$ & & $\sqrt{\square}$ & & & & & \\
\hline Adrenal & $\sqrt{\square}$ & & & & & & & \\
\hline
\end{tabular}


Table 4 Cases of surgical intervention for presumed malignancy prior to diagnosis of IgG4-related disease

\begin{tabular}{|c|c|c|c|c|c|c|}
\hline Patient & Symptoms & Imaging & $\begin{array}{l}\text { Serum } \\
\mathrm{IgG} 4 \\
(\mathrm{~g} / \mathrm{L} ; \\
\text { normal } \\
<1.25)\end{array}$ & $\begin{array}{l}\text { Suspected } \\
\text { malignancy }\end{array}$ & Surgery & Surgical complications \\
\hline $\begin{array}{l}67 \text { South } \\
\text { Asian } \\
\text { female }\end{array}$ & $\begin{array}{l}\text { Abdominal pain, } \\
\text { chronic pancreatitis }\end{array}$ & $\begin{array}{l}\text { High-grade mid to distal small } \\
\text { bowel obstruction, pancreatic } \\
\text { mass }\end{array}$ & 25.7 & Pancreatic & $\begin{array}{l}\text { Whipple resection } \\
1980\end{array}$ & None recorded \\
\hline $\begin{array}{l}55 \text { White } \\
\text { male }\end{array}$ & Epigastric discomfort & $\begin{array}{l}\text { Mediastinal and hilar LAD } \\
\text { concerning pancreatic lesion }\end{array}$ & 2.39 & Pancreatic & $\begin{array}{l}\text { Whipple } \\
\text { resection, } 2016\end{array}$ & None recorded \\
\hline $\begin{array}{l}65 \text { Asian } \\
\text { male }\end{array}$ & $\begin{array}{l}\text { Painless jaundice } \\
\text { Salivary gland } \\
\quad \text { swelling }\end{array}$ & $1.7 \mathrm{~cm}$ mass at head of pancreas & 4.1 & Pancreatic & $\begin{array}{l}\text { Whipple resection } \\
\text { attempt } \\
\text { (aborted } \\
\text { intra-- } \\
\text { operatively), } \\
2010\end{array}$ & None recorded \\
\hline $\begin{array}{l}60 \text { Asian } \\
\text { female }\end{array}$ & $\begin{array}{l}\text { Painless jaundice, } \\
\text { biliary obstruction }\end{array}$ & Stricture of common bile duct & 2.9 & Cholangiocarcinoma & $\begin{array}{l}\text { Extensive bile } \\
\text { duct } \\
\text { reconstruction } \\
\text { and resection of } \\
\text { stricture, } 2019\end{array}$ & $\begin{array}{l}\text { Surgical site infections } \\
\text { with drains requiring } \\
\text { multiple admissions } \\
\text { and long course of } \\
\text { antibiotics }\end{array}$ \\
\hline $\begin{array}{l}68 \text { South } \\
\text { Asian } \\
\text { male }\end{array}$ & $\begin{array}{l}\text { Right renal mass with } \\
\text { adenopathy }\end{array}$ & $\begin{array}{l}\text { Right renal mass } \\
(3.3 \times 1.8 \times 1.7 \mathrm{~cm}) \\
\text { lymphadenopathy along the } \\
\text { aortocaval chains, up to } \\
2.7 \times 1.1 \mathrm{~cm}\end{array}$ & 6.49 & Lymphoma & $\begin{array}{l}\text { Right } \\
\text { nephrectomy } \\
\text { and renal } \\
\text { transplant, } 2014\end{array}$ & $\begin{array}{l}\text { Marginal perfusion to } \\
\text { graft kidney }\end{array}$ \\
\hline $\begin{array}{l}37 \text { Asian } \\
\text { male }\end{array}$ & $\begin{array}{l}\text { Intestinal obstruction, } \\
\text { salivary gland } \\
\text { swelling, hepatic } \\
\text { duct dilation and } \\
\text { CBD stenosis }\end{array}$ & $\begin{array}{l}\text { Multiple lung nodules; } \\
\text { intra-thoracic } \\
\text { lymphadenopathy; right } \\
\text { kidney mass }\end{array}$ & 11.6 & Lymphoma & $\begin{array}{l}\text { Right } \\
\text { nephrectomy, } \\
2001\end{array}$ & Chronic kidney disease \\
\hline $\begin{array}{l}71 \\
\text { Caucas- } \\
\text { ian male }\end{array}$ & Epigastric pain & $\begin{array}{l}\text { Pancreatic mass }(1.9 \times 1.2 \mathrm{~cm}) \\
\text { pre-aortic mass }(3.5 \times 1.4 \mathrm{~cm}) \\
\text { at level of IMA takeoff } \\
\text { Retroperitoneal and iliac } \\
\text { lymphadenopathy }\end{array}$ & 9.75 & $\begin{array}{l}\text { Lymphoma vs. } \\
\text { metastatic } \\
\text { pancreatic cancer }\end{array}$ & $\begin{array}{l}\text { Laparotomy with } \\
\text { removal of } \\
\text { pre-aortic mass, } \\
2014\end{array}$ & $\begin{array}{l}\text { Injury to inferior } \\
\text { mesenteric artery }\end{array}$ \\
\hline $\begin{array}{l}63 \text { Asian } \\
\text { male }\end{array}$ & $\begin{array}{l}\text { Night sweats, weight } \\
\text { loss }\end{array}$ & $\begin{array}{l}\text { Suprarenal right kidney mass } \\
(7.2 \times 6.8 \times 5.4 \mathrm{~cm}) \text { and } \\
\text { splenomegaly }(15 \mathrm{~cm})\end{array}$ & 1.36 & MALT lymphoma & $\begin{array}{c}\text { Para-adrenal mass } \\
\text { resection, } 2018\end{array}$ & Non recorded \\
\hline $\begin{array}{l}67 \text { South } \\
\text { Asian } \\
\text { male }\end{array}$ & $\begin{array}{l}\text { Nausea, vomiting, } \\
\text { bloating }\end{array}$ & $\begin{array}{l}\text { Cecal mass at ileocecal region } \\
\text { with adjacent } \\
\text { lymphadenopathy }\end{array}$ & 1.9 & $\begin{array}{l}\text { Cecal } \\
\text { adenocarcinoma } \\
\text { vs lymphoma }\end{array}$ & $\begin{array}{l}\text { Right } \\
\text { hemicolectomy, } \\
2016\end{array}$ & None recorded \\
\hline $\begin{array}{l}68 \text { Asian } \\
\text { male }\end{array}$ & $\begin{array}{l}\text { Acute urinary } \\
\text { retention, jaundice }\end{array}$ & $\begin{array}{l}\text { Bile duct dilatation, abnormal } \\
\text { prostate gland (irregular } \\
\text { enhancement, peripheral } \\
\text { wedge shaped enhancing } \\
\text { regions) }\end{array}$ & 6.22 & $\begin{array}{l}\text { Prostate vs. } \\
\text { pancreatic }\end{array}$ & $\begin{array}{l}\text { Stent insertion for } \\
\text { distal common } \\
\text { bile duct } \\
\text { stricture, } 2017\end{array}$ & None recorded \\
\hline $\begin{array}{l}41 \text { White } \\
\text { female }\end{array}$ & Malaise, nausea & $\begin{array}{l}\text { Moderate left renal atrophy, } \\
\text { distal abdominal aorta, } \\
\text { inferior vena cava and iliac } \\
\text { vessels surrounded by } \\
\text { confluent soft tissue }\end{array}$ & N/A & Lymphoma & $\begin{array}{l}\text { R kidney } \\
\text { nephrostomy, } \\
2016\end{array}$ & None recorded \\
\hline $\begin{array}{l}73 \text { White } \\
\text { male }\end{array}$ & Painless jaundice & $\begin{array}{l}\text { Intrahepatic duct dilatation with } \\
\text { intraductal sludge/debris; } \\
\text { pancreatic atrophy, scattered } \\
\text { calcifications and duct } \\
\text { dilatation }\end{array}$ & 14.1 & Pancreatic & $\begin{array}{l}\text { Metal biliary stent } \\
\text { insertion, } 2012\end{array}$ & None recorded \\
\hline $\begin{array}{l}73 \text { Asian } \\
\text { male }\end{array}$ & $\begin{array}{l}\text { Abdominal fullness, } \\
\text { jaundice, night } \\
\text { sweats }\end{array}$ & $\begin{array}{l}\text { Changes within the pancreatic } \\
\text { body and tail suggestive of } \\
\text { autoimmune pancreatitis }\end{array}$ & 4.5 & Pancreatic & $\begin{array}{l}2 \times \text { double-pigtail } \\
\text { stents, } 2018\end{array}$ & None recorded \\
\hline $\begin{array}{l}64 \text { Asian } \\
\text { male }\end{array}$ & & $\begin{array}{l}\text { Extensive hepatic hilar mass } \\
\quad(8.3 \times 3 \mathrm{~cm}) \text {; para esophageal, }\end{array}$ & 2.24 & $\begin{array}{l}\text { Cholangiocarcinoma } \\
\text { (Klatskin tumor) }\end{array}$ & $\begin{array}{l}\text { Recurrent stents, } \\
2017\end{array}$ & None recorded \\
\hline
\end{tabular}


Table 4 (continued)

\begin{tabular}{cllll}
\hline Patient & Symptoms & Imaging & $\begin{array}{l}\text { Serum } \\
\text { IgG4 } \\
(\mathrm{g} / \mathrm{L} ; \\
\text { normal } \\
<1.25)\end{array}$ & $\begin{array}{l}\text { Suspected } \\
\text { malignancy }\end{array}$ \\
\hline $\begin{array}{c}\text { Painless biliary } \\
\text { obstruction/- } \\
\text { jaundice }\end{array}$ & $\begin{array}{l}\text { porta hepatis and paraaortic } \\
\text { lymphadenopathy; bulky } \\
\text { pancreas }\end{array}$ & $\begin{array}{l}\text { CA 19-9: 874 kU/L } \\
\text { (reference }<27)\end{array}$ \\
\hline
\end{tabular}

highlighted in literature with numerous case studies and reviews, whereby the initial malignancy diagnosis can lead to delayed initiation of medical treatment, and in some cases, major surgical resections [3, 5, 7-9]. Due to the tumefactive nature of the disease, it can share striking similar presentations and characteristics to malignancy, resulting in the differentiation of the two complicated in many patients.

Although a known fact that IgG4-RD can mimic any malignancy, there are certain types it mimics more than others based on its typical sites of involvement. We aim to analyze the presenting characteristics of IgG4-RD that may be misleading leading to misdiagnosis.

Of the 63 patients in our study, 38 were diagnosed with a malignancy initially, requiring a retrospective revision to IgG4related disease. Fourteen of these patients underwent an invasive intervention due to their initial malignancy diagnosis.

The most common sites of IgG4-RD involvement in our patients included salivary/lacrimal glands (51/63), lymph nodes (18/64), and the pancreas (17/63). These correspond to their common malignant mimicker-exocrine gland/ lymph node swelling can often be seen with lymphoma; pancreas and biliary masses raise alarm bells for pancreatic cancer and cholangiocarcinoma.

There are currently no well-defined imaging-specific findings for IgG4-RD. As seen in Figs. 1, 2, and 3, IgG4-RD may

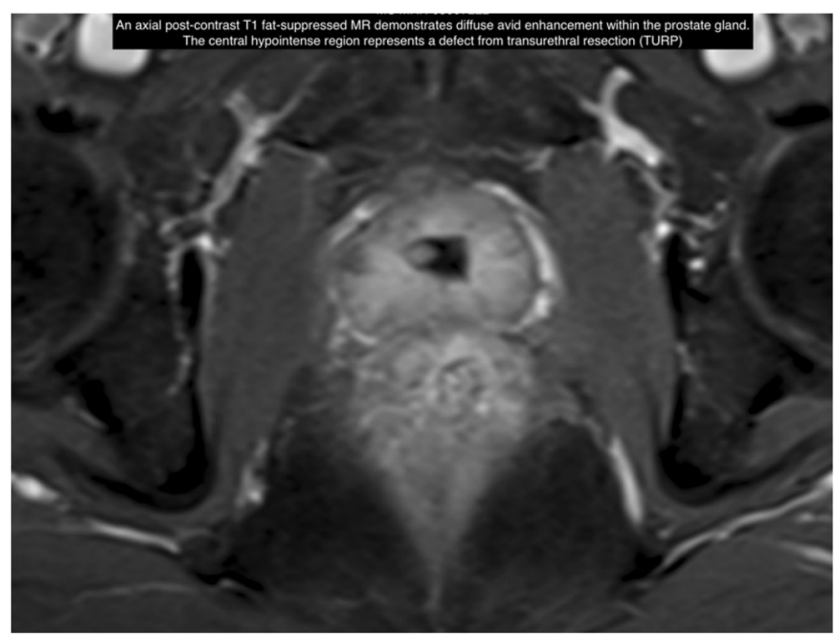

Fig. 1 MRI of IgG4-related prostatitis often present as tumefactive lesion in affected organsmaking a difficult distinction from a malignant mass. On CT imaging, it can present as a homogenous soft tissue mass. On MRI, it can show homogenous or irregular enhancing soft tissue mass in the affected organ. None of our patients had PET scans performed; however, case studies report IgG4-RD lesions showing as hypermetabolic soft tissue lesions [19]. In some cases of diffuse pancreatic involvement of IgG4-RD, however, there has been a specific feature reported; this is a diffuse enlargement with loss of the lobules, resembling a "sausage" with surrounding halo. This is felt to represent infiltration and edema. When this is seen on imaging, it can raise suspicion for IgG4-related pancreatitis [20]. There is currently no specific features for other organ involvements of IgG4-RD. Further studies are needed to investigate differentiating features of IgG4-RD from malignancy on radiographic imaging modalities.

\section{Common Malignancy Mimickers}

Due to the common sites of presentation of IgG4-RD (i.e., pancreas, lymphoid organs, GI tract), the most common malignancy mimickers include lymphoma, pancreatic cancer,

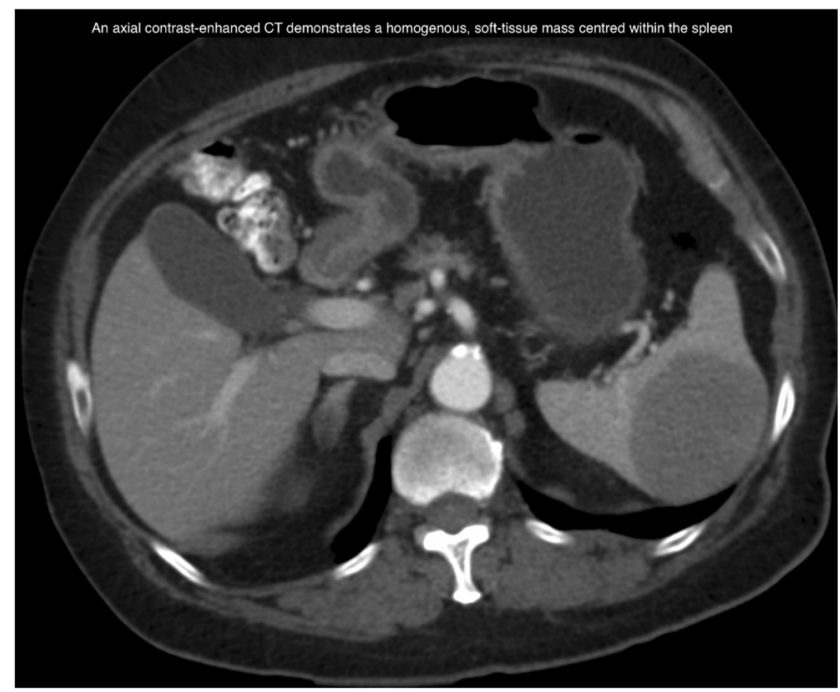

Fig. 2 CT abdomen of spleen involvement in IgG4-RD 


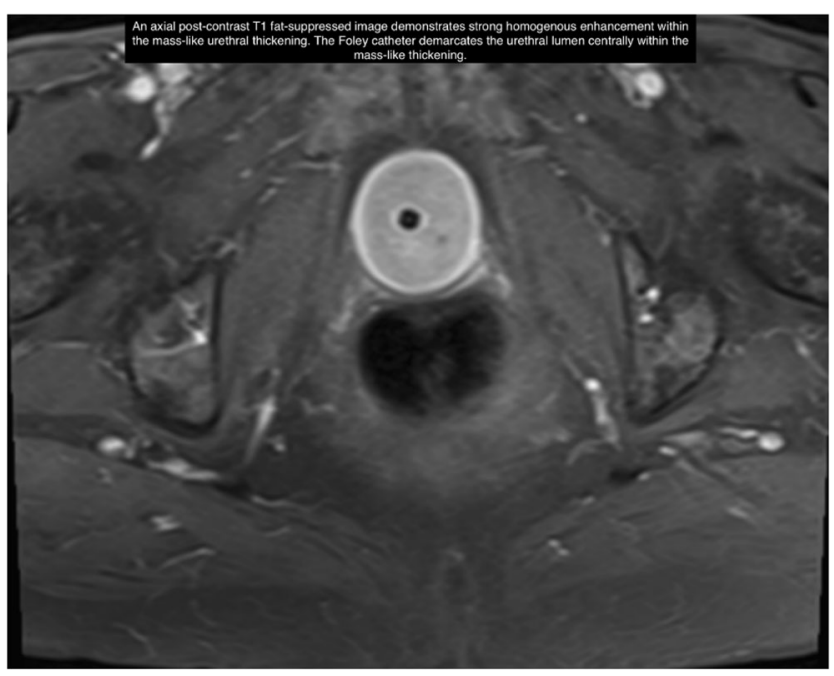

Fig. 3 MRI of urothelial involvement of IgG4-RD

and cholangiocarcinoma. Suspicion for these malignancies in a new patient presentation should prompt consideration of IgG4-RD.

The most common malignant mimicker of IgG4-RD in our patients was lymphoma. Eighteen of the 38 individuals initially thought to have a malignancy were believed to have lymphoma. IgG4-related lymphadenopathy is an immunemediated process characterized by lymphoplasmacytic infiltrates with abundant IgG4-positive plasma cells and fibrosis [21], the morphologic features resembling reactive lymphoid hyperplasia. This finding is not surprising given that lymph node involvement is a common manifestation of IgG4-RD $[12,22]$. There are 5 reported subtypes of IgG4-lymphadenopathy, including multicentric Castleman disease-like changes, follicular hyperplasia, interfollicular lymphoplasmacytic proliferation, progressive transformation of germinal centers, and formation of inflammatory pseudotumor-like lesions [22]. Current studies suggest IgG4-related lymphadenopathy is more common in Asian patients (30-65\% of those with IgG4-RD), compared with patients in the USA and Italy [23]. To further add to the diagnostic challenge, lymph node biopsies often show reactive lymphoid hyperplasia without characteristic histopathologic features of IgG4-RD as it is unusual for lymph nodes to undergo the same degree of fibrosis observed in solid organs [13]. Some clinical differentiators that may be used to favor a diagnosis of IgG4-RD over lymphoma includes the age and gender, whereby IgG4-RD tends to affect middle aged population, and has a male predominance, whereby lymphoma does not typically discriminate in age or gender [13, 24]. In addition, the response to treatment, if it responds to steroids, would highly suggest IgG4-RD over lymphoma [25].

It should be noted that, however, there have been reports of association between IgG4 production and lymphoma [26, 27]. The relationship between IgG4-RD and the subsequent development of hematologic malignancies have not been clearly described or evaluated.

The second and third most common malignant mimickers in our study were pancreatic cancer and cholangiocarcinoma, respectively. IgG4-RD was initially thought to be pancreatic cancer in 11 patients and cholangiocarcinoma in 2 patients. Patients with IgG4-related pancreatitis and/or IgG4-related cholecystitis often present with painless jaundice and obstructive biliary symptoms and imaging often show a pancreatic or biliary mass, all of which may be difficult to distinguish from pancreatic cancer or biliary malignancies [3-5]. In our patient group, there were 17 patients with pancreatic involvement, and 11 were initially thought to have pancreatic cancer. Those with diffuse enlargement of pancreas on imaging were less likely to be misinterpreted as having pancreatic cancer. Typical radiographic findings of autoimmune pancreatitis involve diffusely enlarged pancreatic duct and parenchyma with delayed enhancement caused by fibroinflammatory change of the peripancreatic adipose tissue, which is not commonly seen in malignancies of the pancreas [3]. Of the 17 patients with pancreatic involvement, only 5 had solitary pancreatic involvement, and the remaining patients had concomitant organ involvement, most commonly with salivary/lacrimal glands, kidneys, and liver. Multi-organ involvement should prompt consideration of IgG4-RD.

Other encountered malignant mimickers of IgG4-RD in our study included gastric, colon, renal, prostate cancer, and mesothelioma. Fortunately, all of these patients were correctly diagnosed with IgG4-RD on biopsy prior to undergoing surgical resection for malignancy.

\section{Tumor Markers, serum protein electrophoresis and serum IgG4}

Interestingly, we had one patient (row 14, Table 4) with IgG4related lymphadenopathy and pancreatitis, who was initially believed to have cholangiocarcinoma as he presented with obstructive symptoms and had a tumor marker CA19-9 significantly elevated at $874 \mathrm{kU} / \mathrm{L}$ (reference range $<27$ ). He was diagnosed with IgG4-RD after histopathological tissue analysis, with no evidence of malignancy. CA 19-9 can also be elevated in pancreatitis or biliary obstruction. In patients with mass lesions suspicious for IgG4-RD, serum protein electrophoresis and measurement of IgG subclasses to rule in or rule out elevated serum IgG4 levels are essential. Polyclonal hypergammaglobulinemia is a nonspecific finding seen in liver disease, inflammatory/autoimmune conditions, infection, hematological disorders, and cancer as well as in IgG4related disease [28, 29]. Markedly elevated serum IgG4 typically causes beta-gamma bridging, which can be mistaken for polyclona increase in IgA, so quantitative immunoglobulins by nephelometry are often helpful as well. Although mildy elevated serum IgG4 $1.25-5 \mathrm{~g} / \mathrm{L}$ can be found in many 
conditions such as autoimmune disease, infection, and inflammation, markedly elevated serum IgG4 $>5 \mathrm{~g} / \mathrm{L}$ is about $90 \%$ specific for IgG4-RD [28]. Approximately 30\% of patients with IgG4-RD may have a normal serum IgG4, although serum IgG4 is a much more sensitive test for IgG4-RD in Asians than non-Asians [30, 31]. The serum protein electrophoresis is also important to determine if IgG elevations are polyclonal or monoclonal, as rare cases of IgG4 plasma cell myeloma have been reported [32].

\section{Invasive Intervention}

Fourteen patients in our study underwent invasive intervention tailored to the treatment of their malignant diagnosis. All but one case occurred prior to 2018 , likely due to an increasing recognition for the disease. The interventions included Whipple resection (3/14), interventional-guided biliary stent insertion (4/14), nephrectomy (3/14), mass resection $(2 / 14)$, hemicolectomy (1/14), and biliary reconstruction $(1 / 14)$. Some procedures, such as stenting of biliary and ureteric obstruction, may be considered unavoidable, especially in patients who present with late stage disease.

All 3 patients who underwent Whipple resection had imaging evidence of a discrete pancreatic lesion. Two of these patients had solitary lesions deemed concerning by the radiologist, and one had associated surrounding lymphadenopathy, resulting in small bowel obstruction. In these cases, due to high suspicion on radiographic testing, the patients underwent invasive surgery for a presumed malignancy even prior to confirmatory biopsy testing.

One patient underwent extensive bile duct reconstruction and resection of stricture for symptoms of biliary obstruction. He had common bile duct stricture on imaging. Despite his elevated serum IgG4 (2.9), he underwent extensive surgery for presumed cholangiocarcinoma. He subsequently suffered complications of recurrent surgical site infections.

Four patients underwent interventional radiology guided biliary stenting for presumed cholangiocarcinoma (1/4), and pancreatic cancer (3/4). All 4 patients presented with painless jaundice and had biliary dilatation (intrahepatic or extrahepatic) on imaging.

Six patients were initially diagnosed with lymphoma and underwent surgical resection, with a post-operative correction of the diagnosis to IgG4-RD upon histological analysis. The surgical resections include nephrectomy, pre-aortic mass removal, and hemicolectomy. All of these patients had a discrete mass on imaging with associated surrounding lymphadenopathy, resulting in similarity with lymphoproliferative disorders.
Four of the above patients had complications from their surgery (recurrent surgical site infections, marginal perfusion to graft kidney, chronic kidney disease, injury to inferior mesenteric artery). This highlights the importance of early distinction between IgG4-RD and malignancy, as IgG4-RD responds well to immunosuppressive therapy. Patients with mass lesions suspicious for cancer or IgG4-RD should have serum protein electrophoresis, IgG subclasses, and where, possible, a biopsy to confirm histology prior to undergoing major surgical resection.

\section{Conclusion}

This is the largest study to date to examine IgG4-RD as a mimicker of various malignancies. IgG4-RD is commonly mistaken for cancer, particularly lymphoma and pancreatic cancer, and patients are at risk of delayed diagnosis and surgical procedures. As histopathologic diagnosis is the gold standard for IgG4-RD, an adequate tissue sample is preferred for all patients with the working diagnosis of malignancy vs. IgG4-RD in order to avoid unnecessary invasive interventions. IgG4-RD is readily responsive to steroids and rituximab, and in cases where a biopsy is implausible or contraindicated, a trial of therapy can be pursued to aid in diagnosis.

IgG4-RD should be on the differential diagnosis of patients with mass lesions, in particular those with pancreatic masses and obstructive jaundice, extensive lymphadenopathy, or retroperitoneal masses. Oncologists and other physicians involved in cancer care should be aware of the various manifestations and diagnostic approach to IgG4-RD in order to provide accurate diagnosis and minimize unnecessary invasive procedures.

Abbreviations IgG4-RD, Immunoglobulin G4-Related Disease; ACR, American College of Rheumatology; EULAR, European League Against Rheumatism; CA19-9, carbohydrate antigen 19-9

Acknowledgements All contributors to this manuscript were included in authorship.

Availability of Data and Supporting Materials The datasets used and/or analyzed during the current study are available from the corresponding author on reasonable request.

Author contribution WZ collected data, synthesized results, and formulated the manuscript. TM and SC provided radiographical images. LC aided in data collection. HL, DS, GS, BS, EL, RI, SC, and AM provided expert opinion on patient cases. MC and LC supervised and oversaw the project. All authors reviewed, edited, and approved the manuscript. 


\section{Declarations}

Ethics Approval and Consent to Participate Ethics approval obtained through the clinical research ethics board (H17-02765).

Consent for Publication Consent of publication obtained from patients for figures included in this manuscript.

Competing Interest The authors declare no competing interests.

Open Access This article is licensed under a Creative Commons Attribution 4.0 International License, which permits use, sharing, adaptation, distribution and reproduction in any medium or format, as long as you give appropriate credit to the original author(s) and the source, provide a link to the Creative Commons licence, and indicate if changes were made. The images or other third party material in this article are included in the article's Creative Commons licence, unless indicated otherwise in a credit line to the material. If material is not included in the article's Creative Commons licence and your intended use is not permitted by statutory regulation or exceeds the permitted use, you will need to obtain permission directly from the copyright holder. To view a copy of this licence, visit http://creativecommons.org/licenses/by/4.0/.

\section{References}

1. Chen LYC, Mattman A, Seidman MA, Carruthers MN. IgG4related disease: what a hematologist needs to know. Haematologica. 2019;104(3):444-55.

2. Deshpande V, Zen Y, Chan JK, Yi EE, Sato Y, Yoshino T, et al. Consensus statement on the pathology of IgG4-related disease. Mod Pathol. 2012;25(9):1181-92.

3. Chari ST, Takahashi N, Levy MJ, Smyrk TC, Clain JE, Pearson RK, et al. A diagnostic strategy to distinguish autoimmune pancreatitis from pancreatic cancer. Clin Gastroenterol Hepatol. 2009;7(10):1097-103.

4. Kamisawa T, Funata N, Hayashi Y, Eishi Y, Koike M, Tsuruta K, et al. A new clinicopathological entity of IgG4-related autoimmune disease. J Gastroenterol. 2003;38(10):982-4.

5. Hamano H, Kawa S, Horuichi A, Unno H, Furuya N, Akamatsu T, et al. High serum IgG4 concentrations in patients with sclerosing pancreatitis. N Engl J Med. 2001;344:732-8.

6. Wallace ZS, Naden RP, Chari S, Choi H, Della-Torre E, Dicaire JF, et al. The 2019 American College of Rheumatology/European League against rheumatism classification criteria for IgG4-related disease. Arthritis Rheum. 2020;72(1):7-19.

7. Bookhout CE, Rollins-Raval MA. Immunoglobulin G4-related lymphadenopathy. Surg Pathol Clin. 2016;9(1):117-29.

8. Lang D, Zwerina J, Pieringer H. IgG4-related disease: current challenges and future prospects. Ther Clin Risk Manag. 2016;12:189 99.

9. Inoue D, Yoshida K, Yoneda N, Ozaki K, Matsubara T, Nagai K, et al. IgG4-related disease: dataset of 235 consecutive patients. Medicine (Baltimore). 2015;94(15):e680.

10. Varghese JL, Fung AWS, Mattman A, Quach TTT, Gauiran DTV, Carruthers MN, et al. Clinical utility of serum IgG4 measurement. Clin Chim Acta. 2020;506:228-35.

11. Lei WH, Xin J, Shao CX, Mao MF, Zhu CY, Wu CF, et al. IgG4related kidney disease mimicking malignant ureter tumor: case report and literature review. Medicine (Baltimore). 2016;95(3): e2550.

12. Liu Y, Xue F, Yang J, Zhang Y. Immunoglobulin G4-related disease mimicking lymphoma in a Chinese patient. Rheumatol Int. 2015;35(10):1749-52.

13. Bai Z, Chen Y, Chen X, Dong L. A medical mirroring: chronic myelomonocytic leukemia mimicking immunoglobulin G4related disease. Am J Transl Res. 2019;11(7):4561-7.

14. Wallace ZS, Wallace CJ, Lu N, Choi HK, Stone JH. Association of IgG4-related disease with history of malignancy. Arthritis Rheum. 2016;68(9):2283-9.

15. Bledsoe JR, Wallace ZS, Stone JH, Deshpande V, Ferry JA. Lymphomas in IgG4-related disease: clinicopathologic features in a Western population. Virchows Arch. 2018;472(5):839-52.

16. Yamamoto M, Takahashi H, Tabeya T, Suzuki C, Naishiro Y, Ishigami $\mathrm{K}$, et al. Risk of malignancies in IgG4-related disease. Mod Rheumatol. 2012;22(3):414-8.

17. Gou SJ, Xue LJ, Hu ZX. Simultaneous occurrence of IgG4-related tubulointerstitial nephritis and colon adenocarcinoma with hepatic metastasis: a case report and literature review. BMC Nephrol. 2019;20(1):23.

18. van der Gugten G, DeMarco ML, Chen LYC, Chin A, Carruthers $\mathrm{M}$, Holmes DT, et al. Resolution of spurious immunonephelometric IgG subclass measurement discrepancies by LC-MS/MS. Clin Chem. 2018;64(4):735-42.

19. Haider M, Haji F, Alalwan O, Aljufairi E, Shah TS. IgG4-related disease, the malignancy mimicker: case series from Bahrain. Case Rep Rheumatol. 2018;2018:4057024.

20. Martinez-de-Alegria A, Baleato-Gonzalez S, Garcia-Figueiras R, Bermudez-Naveira A, Abdulkader-Nallib I, Diaz-Peromingo JA, et al. IgG4-related disease from head to toe. Radiographics. 2015;35(7):2007-25.

21. Sulieman I, Mahfouz A, AlKuwari E, Szabados L, Elmoghazy W, Elaffandi A, et al. IgG4-related disease mimicking pancreatic cancer: case report and review of the literature. Int J Surg Case Rep. 2018;50:100-5.

22. Wick MR, O'Malley DP. Lymphadenopathy associated with IgG4related disease: diagnosis \& differential diagnosis. Semin Diagn Pathol. 2018;35(1):61-6.

23. Li PH, Ko KL, Ho CT, Lau LL, Tsang RK, Cheung TT, et al. Immunoglobulin G4-related disease in Hong Kong: clinical features, treatment practices, and its association with multisystem disease. Hong Kong Med J. 2017;23(5):446-53.

24. Peng Y, Li JQ, Zhang PP, Zhang X, Peng LY, Chen H, et al. Clinical outcomes and predictive relapse factors of IgG4-related disease following treatment: a long-term cohort study. J Intern Med. 2019;286(5):542-52.

25. Azuma S, Kurita A, Yazumi S. Hepatobiliary and pancreatic: Burkitt lymphoma mimicking IgG4-related disease. J Gastroenterol Hepatol. 2018;33(10):1694.

26. Igawa $\mathrm{T}$, Hayashi $\mathrm{T}$, Ishiguro $\mathrm{K}$, Maruyama $\mathrm{Y}$, Takeuchi $\mathrm{M}$, Takata $\mathrm{K}$, et al. IgG4-producing lymphoma arising in a patient with IgG4related disease. Med Mol Morphol. 2016;49(4):243-9.

27. Cheuk W, Yuen HK, Chan AC, Shih LY, Kuo TT, Ma MW, et al. Ocular adnexal lymphoma associated with IgG4+ chronic sclerosing dacryoadenitis: a previously undescribed complication of IgG4related sclerosing disease. Am J Surg Pathol. 2008;32(8):1159-67.

28. Zhao EJ, Cheng CV, Mattman A, Chen LYC. Polyclonal hypergammaglobulinaemia: assessment, clinical interpretation, and management. The Lancet Haematology. 2021;8(5):e365-75.

29. Zhao EJ, Carruthers MN, Li CH, Mattman A, Chen LYC. Conditions associated with polyclonal hypergammaglobulinemia 
in the IgG4-related disease era: a retrospective study from a hematology tertiary care center. Haematologica. 2020;105(3):e121-3.

30. Qi R, Chen LYC, Park S, Irvine R, Seidman MA, Kelsall JT, et al. Utility of serum IgG4 levels in a multiethnic population. Am J Med Sci. 2018;355(1):61-6.

31. Harkness T, Fu X, Zhang Y, Choi HK, Stone JH, Blumenthal KG, et al. Immunoglobulin $\mathrm{G}$ and immunoglobulin $\mathrm{G}$ subclass concentrations differ according to sex and race. Ann Allergy Asthma Immunol. 2020;125(2):190-195 e192.

32. Gauiran DTV, Marcon KM, DeMarco ML, et al. IgG4 plasma cell myeloma without clinical evidence of IgG4-related disease: a report of two cases. Hematology. 2020;25(1):335-40.
Publisher's Note Springer Nature remains neutral with regard to jurisdictional claims in published maps and institutional affiliations.

Novelty Statement This is the largest case review in literature highlighting the similarity in presentation between IgG4-RD and its common malignancy mimickers. In several of our cases, patients believed to have a malignancy underwent invasive intervention, even prior to histopathological confirmation of the diagnosis, only to have a retrospective revision of their diagnosis to but were subsequently found to have IgG4-RD. A IgG4-RD disease typically responds to medical therapies such as rituximab and corticosteroids. Oncologists and clinicians involved in cancer care should be aware of the various manifestations of, and the diagnostic approach to, IgG4-RD. 